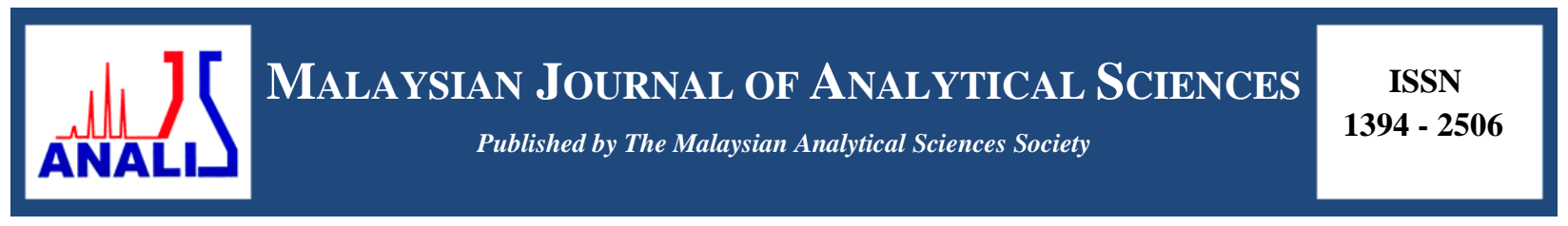

\title{
ADSORPTION OF ANIONIC DYES FROM AQUEOUS SOLUTIONS BY CALCINED AND UNCALCINED Mg/Al LAYERED DOUBLE HYDROXIDE
}

\author{
(Penjerapan Pewarna Ionik daripada Larutan Akues Menggunakan Mg/Al Dwi-Hidroksida \\ Berlapis Berkalsin dan Tanpa Kalsin)
}

\author{
Siti Mariam Sumari*, Zaini Hamzah, Nesamalar Kantasamy \\ Faculty of Applied Sciences, \\ Universiti Teknologi MARA, 40450 Shah Alam, Selangor, Malaysia \\ *Corresponding author: sms21vic@gmail.com
}

Received: 9 December 2015; Accepted: 6 May 2016

\begin{abstract}
The uptake of Acid Blue 29 (AB29), Reactive Orange 16 (RO16) and Reactive Red 120 (RR120) from aqueous solutions by calcined $(\mathrm{CLDH})$ and uncalcined $\mathrm{Mg} / \mathrm{Al}$ layered double hydroxide ( $\mathrm{LDH}$ ) has been investigated. The adsorption process was conducted in a batch mode at $25^{\circ} \mathrm{C}$. Anionic dye removal was more efficient using the CLDH rather than LDH. The adsorption process by CLDH involved reconstruction and hydration of the calcined LDH and intercalation of AB29, RO16 and RR120. Physical characterization using X-Ray Diffraction (XRD), Scanning Electron Microscopy (SEM) and Fourier Transform Infrared (FTIR) were used to ascertain the 'memory effect' phenomenon that is structural reconstruction to regain its original LDH after rehydration. To gain insight into the mechanism of adsorption by CLDH, the pseudo-first order (PFO) and pseudo-second order (PSO) and intraparticle diffusion (IPD) kinetic models were used to analyse experimental data. Based on the correlation coefficient $\left(R^{2}\right)$, the PSO has better fitting $\left(R^{2}=0.987-1.00\right)$ compared to PFO $\left(R^{2}=0.867-0.990\right)$. Furthermore the values of maximum adsorption capacity, $\left(q_{\mathrm{e}}\right)$ calculated from PSO model are consistent with the experimental $q_{\mathrm{e}}$ indicating that the experimental kinetic data for AB29, RO16 and RR120 adsorption by CLDH are suitable for this model. Recycling of the adsorbent, in cycles of calcination-reconstruction process promised a possibility of regeneration of CLDH.
\end{abstract}

Keywords: calcined, adsorption capacity, reconstruction, memory effect, regeneration

\section{Abstrak}

Penyingkiran pewarna Acid Blue 29 (AB29), Reactive Orange 16 (RO16) dan Reactive Red 120 (RR120) daripada larutan akues menggunakan $\mathrm{Mg} / \mathrm{Al}$ dwi-hidroksida berlapis berkalsin (CLDH) dan tanpa kalsin (LDH) telah dilakukan menggunakan kaedah berkelompok pada suhu $25{ }^{\circ} \mathrm{C}$. Penjerapan bahan pewarna menggunakan CLDH didapati lebih berkesan berbanding LDH. Penjerapan bahan pewarna oleh CLDH berlaku melibatkan proses penghidratan dan penstrukturan semula CLDH dan juga apitan AB29, RO16 dan RR120. Pencirian fizikal pada bahan penjerap yang diperolehi dengan menggunakan kaedah Pembelauan Sinar-X (XRD), Mikroskopi Imbasan Elektron (SEM) dan Spektroskopi Inframerah Transformasi Fourier (FTIR) telah digunakan untuk mengenalpasti fenomena 'kesan memori', iaitu proses penstrukturan semula kepada LDH selepas berlaku penghidratan. Cerapan lebih lanjut mengenai mekanisme proses penjerapan ini, model-model kinetik pseudo tertib pertama (PFO), pseudo tertib kedua (PSO) dan resapan intrapartikel (IPD) telah digunakan untuk menganalisis data ujian. Berdasarkan nilai pekali korelasi $\left(R^{2}\right)$, model PSO didapati lebih sesuai $\left(R^{2}=0.99-1.00\right)$ berbanding PFO $\left(R^{2}=0.85-0.99\right)$. Fakta ini diperkukuhkan lagi dengan nilai kapasiti penjerapan maksimum, $\left(q_{\mathrm{e}}\right)$ hasil pengiraan menggunakan PSO yang didapati konsisten dengan $q_{\mathrm{e}}$ ujian $\left(q_{\mathrm{e}}\right.$, expt. $)$ untuk AB29, RO16 dan RR120. Kitaran semula bahan penjerap melalui beberapa siri kitaran pengkalsinan-penstrukturan semula juga didapati dapat menjanjikan penjanaan semula CLDH. 


\section{Siti Mariam et al: ADSORPTION OF ANIONIC DYES FROM AQUEOUS SOLUTIONS BY CALCINED AND UNCALCINED Mg/Al LAYERED DOUBLE HYDROXIDE}

Kata kunci: berkalsin, kapasiti penjerap, penstrukturan semula, kesan memori, penjanaan semula

\section{Introduction}

Dyehouse effluent usually contain various types of dye classes such as azo, anthraquinone, triphenylmethane,etc. Most of them are synthetic aromatic benzenoid compounds with potential toxic, mutagenic and carcinogenic properties, endangering human health and environment [1]. Generally, they are difficult to treat by conventional water treatment as they are structurally stable to biodegradation [2,3].The most efficient colour removal from aqueous solution has been attributed to adsorption, which largely employs activated carbon (AC) as adsorbent. Since AC is commercially costly for large scale production and difficult to regenerate, alternative adsorbents are being sought. A positively charged anionic clay known as layered double hydroxide (LDH), with an empirical formula $\left[\mathrm{M}^{\mathrm{II}}{ }_{1-x} \mathrm{M}^{\mathrm{III}}{ }_{x}(\mathrm{OH})_{2}\right]^{x+}\left[\mathrm{A}^{n-}{ }_{x / n} \cdot m \mathrm{H}_{2} \mathrm{O}\right]^{x-}$, where $\mathrm{M}^{\mathrm{II}}=\mathrm{Zn}, \mathrm{Mg}, \mathrm{Co}, \mathrm{Ni}$ and $\mathrm{M}^{\mathrm{III}}=\mathrm{Al}, \mathrm{Fe}, \mathrm{Cr}, \mathrm{Ga}$, etc., $\mathrm{A}^{n^{-}}=$ $\mathrm{CO}_{3}^{2-}, \mathrm{NO}_{3}^{-}, \mathrm{Cl}^{-}, \mathrm{SO}_{4}^{2-}[4,5]$ is known for its versatile applications as well as excellent adsorbent for anionic species in aqueous solution.

Calcination of LDHs at temperature $400-700{ }^{\circ} \mathrm{C}$ can decompose LDH containing carbonate or nitrate to release $\mathrm{CO}_{2}$ or $\mathrm{NO}_{x}$ gas with end products containing a solid mixture of $\mathrm{Mg}-\mathrm{Al}$ oxide, which can revert to the original structure (reconstruction) of LDH upon rehydration [1,6]. This phenomenon, well known as 'memory effect' was responsible for enhanced uptake of anionic dye removal by CLDH in comparison to its precursor LDH. The objective of this study is to investigate the kinetic behaviour of AB29, RO16 and RR120 adsorption by CLDH in comparison to its precursor $\mathrm{LDH}$, while at the same time to assess the possibility of regeneration of the adsorbent. Kinetic parameters are important pre-requisites for eventual design of water treatment processes employing the use of adsorbents such as LDH/CLDH. XRD, FTIR and SEM were used to characterize the adsorbents before and after dye adsorption by CLDH. Kinetic models, Lagergren's pseudo-first order [7], Ho's pseudo-second order [8] and intraparticle diffusion [9] were used to gain understanding of the adsorption mechanism of by CLDH.

Therefore, desorption or calcination study was undertaken to evaluate the prospect of regeneration and reuse of the adsorbent.

\section{Preparation of adsorbent LDH by co-precipitation method}

Synthesis of layered double hydroxide $(\mathrm{LDH})$ of the formula, $\left[\mathrm{M}_{1-\mathrm{x}}^{2+} \mathrm{M}_{\mathrm{x}}^{3+}(\mathrm{OH})_{2}\right] \mathrm{A}_{\mathrm{x} / \mathrm{n}}^{\mathrm{n}-} \cdot \mathrm{mH}_{2} \mathrm{O}$ with $\mathrm{M}^{2+}=\mathrm{Mg}^{2+}$, $\mathrm{M}^{3+}=\mathrm{Al}^{3+}$ and interlayer anion, $\mathrm{A}^{\mathrm{n}-}=\mathrm{NO}_{3}^{-}$was conducted by coprecipitation procedure followed by hydrothermal treatment as outlined by several authors [10 - 12], with slight modification. A solution of $\mathrm{Mg}\left(\mathrm{NO}_{3}\right)_{2} \cdot 6 \mathrm{H}_{2} \mathrm{O}$ and $\mathrm{Al}\left(\mathrm{NO}_{3}\right)_{3} \cdot 9 \mathrm{H}_{2} \mathrm{O}$ with molar ratio of $\mathrm{Mg} / \mathrm{Al}: 4 / 1$ were allowed to mix with $1 \mathrm{M} \mathrm{NaOH}$ by drop wise addition of $\mathrm{NaOH}$ at a rate of $1 \mathrm{~mL} / \mathrm{min}$, stirring the mixture all the time using a magnetic stirrer, while keeping $\mathrm{N}_{2}$ gas bubbling in the solution mixture throughout the coprecipitation process. This was to minimize the inclusion of $\mathrm{CO}_{2}$ in the solution. The $\mathrm{N}_{2}$ addition was allowed to continue until the solution's $\mathrm{pH}$ reading reached $10.0 \pm 0.5$ in a $1 \mathrm{~L}$ beaker. The resulting heavy slurry was poured into stoppered glass bottles, and then aged in a thermostated oil bath shaker operating at $70{ }^{\circ} \mathrm{C}, 100 \mathrm{rpm}$ for 24 hours duration. Once the resulting white precipitate was cooled, it was washed several times with distilled water until the $\mathrm{pH}$ reached $7-8$, to get rid of excess alkali, after which the solid was separated out by vacuum filtration. The final white solid, named layered double hydroxide (LDH) was dried (80 ${ }^{\circ} \mathrm{C}, 24$ hours) before being ground and sieved.

\section{Preparation of calcined LDH}

Calcination of the synthesized LDH was carried out by heating LDH at a designated temperature (100, 200, 300, $400,500,600$ and $700{ }^{\circ} \mathrm{C}$ ) in a furnace (Lenton, UK) for 8 hours. The calcined product (henceforth referred to as CLDH100, CLDH200, etc.) was stored in a desiccator prior to characterization and adsorption studies. The calcined product (CLDHs) were subjected to contact time experiment to study which CLDH (CLDH100, CLDH200, CLDH300, etc.) gave the highest percentage of dye removal and adsorption capacity, and consequently selected for adsorption by CLDH in comparison with its precursor LDH. In carrying out this experiment for a particular dye, the dosage and volume $(W / V)$ were kept constant. 


\section{Preparation of adsorbates}

Aqueous stock solutions (1000 mg/L) of RR120, RO16 and AB29 were prepared, from which diluted solutions were obtained for batch adsorption analysis. The chemical structures and physical properties of the three dyes are shown in Figure 1.

$\begin{array}{ll}\text { C.I Name } & \text { Acid blue 29 (AB29) } \\ \text { C.I No } & 20460 \\ \text { Formula Weight } & 616.49 \\ \text { Class } & \text { Diazo } \\ \lambda_{\max } & 602 \mathrm{~nm} \\ \text { Mol. Formula } & \mathrm{C}_{22} \mathrm{H}_{14} \mathrm{~N}_{6} \mathrm{Na}_{2} \mathrm{O}_{9} \mathrm{~S}\end{array}$<smiles>Nc1c(N=Nc2cccc([N+](=O)[O-])c2)c([N+](=O)[O-])cc2cc([N+](=O)[O-])c(N=Nc3ccccc3)c(O)c12</smiles>

$\begin{array}{ll}\text { C.I Name } & \text { Reactive Orange 16 } \\ \text { C.I No } & 17757 \\ \text { Formula Weight } & 617.53 \\ \text { Class } & \text { Azo } \\ \lambda_{\max } & 494 \mathrm{~nm} \\ \text { Mol. Formula } & \mathrm{C}_{20} \mathrm{H}_{17} \mathrm{~N}_{3} \mathrm{Na}_{2} \mathrm{O}_{11} \mathrm{~S}\end{array}$<smiles>CCC(=O)ON(C(C)=O)S(=O)(=O)c1ccc(N=Nc2c([N+](=O)[O-])cc3ccc(NC(C)=O)cc3c2O)cc1</smiles>

$\begin{array}{ll}\text { C.I Name } & \text { Reactive Red } 120 \\ \text { C.I No } & 25810 \\ \text { Formula Weight } & 1469.43 \\ \text { Class } & \text { Azo, Triazine } \\ \lambda_{\max } & 532 \mathrm{~nm} \\ \text { Mol. Formula } & \mathrm{C}_{44} \mathrm{H}_{24} \mathrm{Cl}_{2} \mathrm{~N}_{14} \mathrm{Na}_{6} \mathrm{O}_{20} \mathrm{~S}\end{array}$

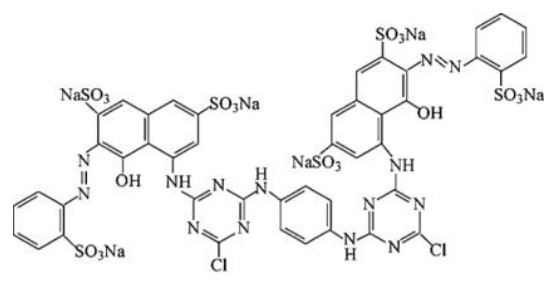

Figure 1. Chemical structures and physical properties of AB29, RO16 and RR120

\section{Adsorption by calcined LDH (CLDH) and uncalcined LDH}

The adsorption of AB29, RO16 and RR120 by LDH and CLDH was conducted in a batch mode in duplicates using initial concentration ranging from 50 to $100 \mathrm{mg} / \mathrm{L}$ with a constant dose of $0.2 \mathrm{~g} / \mathrm{L}$ adsorbent at $25 \pm 1{ }^{\circ} \mathrm{C}$ in a thermostated water bath shaker, operating at $100 \mathrm{rpm}$. Since a previous separate experiment had shown that maximum removal for anionic and acidic dyes occurred at mild acidic $\mathrm{pH}$, the batch adsorption of dyes under study was conducted at the $\mathrm{pH}$ of natural solutions without $\mathrm{pH}$ adjustment since the dyes are weakly acidic $(5.6-6.6)$. This would be cost saving procedure since no extra cost for chemicals would be necessary. At the end of predetermined contact time $(0-1440 \mathrm{~min})$, the solution was filtered using $0.45 \mu \mathrm{m}$ cellulose nitrate syringe filter (Whatman) so the remaining dye left in the solution can be measured using UV-Vis spectrophotometer (Secoman UVIKON SL/XS (M8307) at the wavelength of maximum absorption of each dye (Figure 1).

Adsorption data obtained were analysed for amount of dye adsorbed by the LDH and CLDH in terms of adsorption capacity $\left(q_{\mathrm{t}}, \mathrm{mg} / \mathrm{g}\right)$ and percentage dye removal (\%) using the Equation (1) and (2), respectively

$$
\text { Adsorption capacity, } q_{t}(\mathrm{mg} / \mathrm{g})=\frac{\left(C_{0}-C_{t}\right) V}{W}
$$




$$
\text { Dye removal }(\%)=\frac{\left(C_{0}-C_{t}\right)}{C_{0}} \times 100
$$

where, $q_{\mathrm{t}}$ is adsorption capacity in $\mathrm{mg} / \mathrm{g}, C_{\mathrm{o}}$ and $C_{t}$ are initial and final dye concentrations $(\mathrm{mg} / \mathrm{L})$ after treatment for certain period of time, $t ; V$ is the volume of each dye solution (L) and $W$ is the weight of adsorbent $(\mathrm{g})$. At equilibrium time $t_{\mathrm{e}}, q_{\mathrm{t}}=q_{\mathrm{e}}$.

\section{Kinetic modeling}

The data obtained from these experiments were used to evaluate the kinetic parameters. To gain insight into the mechanism of adsorption by LDH and CLDH, pseudo-first order (PFO) (Equation 3a), pseudo-second order (PSO) (Equation 4a) and intra-particle diffusion models (IPD) (Equation 5) were applied.

\section{Pseudo-first order (PFO) model}

The linear expression based on Lagergren's PFO rate equation [7] is represented by Eq. (3a):

$$
\log \left(q_{e}-q_{t}\right)=\log q_{e}-\frac{k_{1} t}{2.303}
$$

The initial rate $h_{l}(\mathrm{mg} / \mathrm{g}$. min), at $t=0$ is defined by the following expression:

$$
h_{1}=k_{1} q_{e}
$$

A linear plot of $\log \left(q_{\mathrm{e}}-q_{t}\right)$ versus $t$ enables the determination of $k_{1}(1 / \mathrm{min})$ and $q_{e}$ from the gradient and intercept of the plot.

\section{Pseudo-second order (PSO) model}

The linear expression for Ho's PSO rate equation [8] is represented by Equation (4a):

$$
\frac{t}{q_{t}}=\frac{1}{k_{2} q_{e}^{2}}+\frac{t}{q_{e}}
$$

The initial rate $h_{2}(\mathrm{mg} / \mathrm{g}$. min), at $t=0$ is defined by the following equation:

$$
h_{1}=k_{2} q_{e}^{2}
$$

A linear plot of $t / q_{\mathrm{t}}$ versus $t$ enables the determination of $k_{2}(\mathrm{~g} / \mathrm{mg} \cdot \mathrm{min})$ and $q_{\mathrm{e}}$, from the intercept and the slope.

\section{Intraparticle diffusion (IPD) model}

The possibility of IPD resistance affecting adsorption was explored by using the Weber-Morris IPD model [9] is represented by Equation (5):

$$
q_{t}=k_{p} t^{0.5}+C
$$

where $k_{\mathrm{p}}\left(\mathrm{g} / \mathrm{mg}\right.$.min) is the intraparticle diffusion rate constant and $C$. By plotting $q_{\mathrm{t}}$ versus $t^{0.5}$, the values of $k_{\mathrm{p}}$ was calculated from the slope. The value of constant $\mathrm{C}$ can be found from the intercept and is a measure of the thickness of boundary layer. Hence, the higher value of $\mathrm{C}$, the greater the effect of boundary layer [13]. Based on IPD theory, the plot is linear if intraparticle diffusion is involved in the adsorption process. Additionally, if these lines pass through the origin then intra particle diffusion is the rate controlling step [14,15].

\section{Desorption and regeneration}

The residue after initial adsorption ( 0 cycle) by CLDH was thermally treated at its calcination temperature and the final product (regenerated CLDH) was again subjected to dye adsorption $\left(1^{\text {st }}\right.$ cycle). This process was repeated until 
the $4^{\text {th }}$ cycle when the percentage removal of dye became less than $25-30 \%$. The reusability of regenerated adsorbent was based on percentage dye removal calculated for each cycle using Equation 2.

\section{Characterization}

Powder X-Ray Diffraction (PXRD) is a technique used to characterize the crystallite size (grain size), crystallographic structure, and the preferred orientation in polycrystalline or powdered solid samples. The X-ray diffraction (XRD) patterns of LDHs and CLDHs before and after adsorption were recorded using a PanAlytical (Germany) diffractometer under the following conditions: $40 \mathrm{kV}, 25 \mathrm{~mA}$, Ni-filtered $\mathrm{Cu}-\mathrm{K} \alpha$ radiation $(\lambda=1.542 \AA)$ and scanning rate of $2 \theta / \mathrm{min}$ in the range of $10-70{ }^{\circ} \mathrm{C}$. The XRD patterns enable the elucidation of basal spacings (d-spacings) of LDHs and CLDHs at pre or post adsorption of dye and give some indications of any change in crystallographic structure. Microstructural examination of LDH and CLDH was carried out using a Carl Zeiss SMTSupra 40VP (Germany) scanning electron microscope (SEM) to study surface morphologies. The specific surface area of LDH and CLDH was obtained from adsorption/desorption isotherm of liquid $\mathrm{N}_{2}$ at $-196{ }^{\circ} \mathrm{C}$ following the standard Brunauer, Emmett and Teller (BET) method using using Micromeritics surface area analyser (USA).

\section{Calcination temperature of $\mathrm{Mg} / \mathrm{Al} \mathrm{LDH}$}

\section{Results and Discussion}

Figure 2 shows the results based on a preliminary investigation on percentage of dye removal using LDH calcined at various temperatures $\left(200-700{ }^{\circ} \mathrm{C}\right)$. It is obvious that dye removal percentage was highest with LDH calcined at $500{ }^{\circ} \mathrm{C}$ (CLDH500). Upon calcination, LDH was transformed to aluminium and magnesium oxides by the loss of interlayer anions, causing the adsorption of dye to increase in the temperature range $200-500{ }^{\circ} \mathrm{C}$, reaching the highest at $500{ }^{\circ} \mathrm{C}$, corresponding to complete or almost complete decomposition of interlayer nitrate (Equation 6). Until this stage, the process was reversible; it was able to reconstruct its original LDH structure (memory effect) by incorporating anions such as water or anionic dyes or others (Equation 7). Above $500{ }^{\circ} \mathrm{C}$, CLDH was transformed into a spinel which lost the property of reconstruction and reversibility, resulting in the observed decrease in dye adsorption. Other researchers using calcined $\mathrm{Mg} / \mathrm{Al}-\mathrm{LDH}$ to remove pollutants had also used the same temperature $\left(500{ }^{\circ} \mathrm{C}\right)$ to obtain calcined LDH $[16-18]$. Based on this result, subsequent adsorption experiment was conducted using CLDH500.

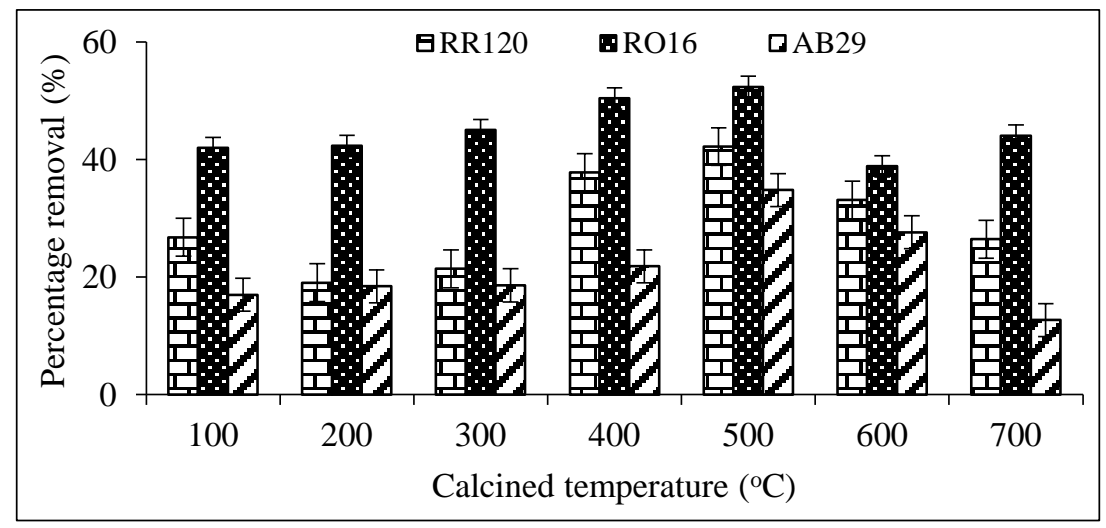

Figure 2. Percentage of dye removal by CLDHs calcined at different temperatures

Decomposition:

$$
\mathrm{Mg}_{1-x} \mathrm{Al}_{x}(\mathrm{OH})_{2}\left(\mathrm{NO}_{3}\right)_{x / 2} \cdot m \mathrm{H}_{2} \mathrm{O} \stackrel{500{ }^{\circ} \mathrm{C}}{\longrightarrow} \mathrm{Mg}_{1-x} \mathrm{Al}_{x} \mathrm{O}_{1+x / 2}+\left(x / 2 \mathrm{NO}_{2}\right)+(m+1) \mathrm{H}_{2} \mathrm{O}
$$


$\begin{array}{ll}\text { Siti Mariam et al: } & \text { ADSORPTION OF ANIONIC DYES FROM AQUEOUS SOLUTIONS BY CALCINED AND } \\ \text { UNCALCINED Mg/Al LAYERED DOUBLE HYDROXIDE }\end{array}$

Regeneration:

$$
\mathrm{Mg}_{1-x} \mathrm{Al}_{x} \mathrm{O}_{1+x / 2}+(x / \mathrm{n}) \mathrm{A}^{\mathrm{n}-}+(m+1+(x / 2)+y) \mathrm{H}_{2} \mathrm{O} \longrightarrow \mathrm{Mg}_{1-x} \mathrm{Al}_{x}(\mathrm{OH})_{x}\left(\mathrm{~A}^{n-}\right)_{x / n} \cdot m \mathrm{H}_{2} \mathrm{O}+x \mathrm{OH}^{-}
$$

\section{Characterization of calcined and uncalcined LDH}

\section{$X$-Ray diffraction}

The XRD pattern of precursor LDH in Figure 3(a) consists of three intense lines at low $2 \theta$ angle equivalent to diffraction by planes (003), (006) and (009) [7]. These sharp and symmetric peaks indicate the formation of a single well crystallized $\mathrm{MgAlNO}_{3}$. The interlayer distance or $\left(d_{003}\right)$ and $\left(d_{006}\right)$ of LDHs corresponding to $8.01 \AA$ and 3.99 $\AA$, are due to basal reflections of crystal lattice, indicating successive layer stacking of the brucite-like lamellar sheets of hydrotalcite-like LDHs (ICSD collection code 086655). These values, together with other non- basal spacings at $1.54 \AA\left(d_{110}\right)$ and $1.51 \AA\left(d_{113}\right)$ are consistent with typical XRD pattern of LDH as reported by several authors $[1,3,19-21]$

Calcination up to $500{ }^{\circ} \mathrm{C}$ led to the progressive loss of physiosorbed water molecules, then the interlayer water and finally water from dehydroxylation of the brucite layer. The dehydration process was accompanied by the loss of interlayer anion leading to the collapse of the lamellar structure of $\mathrm{LDH}$ with the formation of mixed metal oxides $\mathrm{MgO}-\mathrm{AI}_{2} \mathrm{O}_{3}$. As implied in the XRD pattern in Figure 3(b), the layered structure of the original LDHs has been destroyed in CLDH500 (CLDH) as evident from the significant absence of $d_{006}$ and $d_{003}$ peaks. Instead broad diffraction peaks appeared suggesting low structural order with almost total decomposition of the original LDHs with elimination of most interlayer nitrate anions and water. The XRD patterns of CLDH now resemble that of rock salt $\mathrm{MgO}$ whose reflection has shifted to higher angle due to the presence of $\mathrm{Al}^{3+}$ in in $\mathrm{Mg}_{(1-x)} \mathrm{Al}_{x} \mathrm{O}_{(1+x / 2)}$ [17]. No separated phases for $\mathrm{Al}^{3+}$ cations $\left(\mathrm{Al}_{2} \mathrm{O}_{3}\right)$ were observed, indicating that these cations were dispersed in the $\mathrm{MgO}$ matrix solid solution [19], which is capable of being restored to LDH when rehydrated [5]. These observations were consistent with CLDH patterns cited in the literatures [1, 3, 17]. Figures 3(c-e) also shows that the diffraction patterns of dye- loaded CLDHs displaying peaks corresponding to $\left(d_{003}\right)$ and $\left(d_{006}\right)$ which are similar to the original LDH's XRD pattern. However the resulting peaks were broadened and with decreased peak intensity. This implies some reduction in crystallinity as a result of calcinations, rehydration and structural reconstruction which have occurred [21]. Due the 'memory effect', the CLDH was able to reconstruct and regain its original LDH when rehydrated [5].

After reconstruction, the basal spacings, notably $\left(d_{003}\right)$ were observed to have increased in the dye-loaded CLDH (8.55 $\AA$, $8.47 \AA$ and $8.86 \AA$ ), indicating some increase in the interlayer distance. Theoretically, the increase in basal spacing $\left(\mathrm{d}_{003}\right)$ and $\left(\mathrm{d}_{006}\right)$ may indicate some dyes were intercalated into the spacing. Being bigger molecule than nitrate, the dye intercalated in the interlayer spacing was expected to result in an increase of the basal spacing or gallery height of the lamellar LDH. However, since the increase was not significantly large, it considered that total intercalation has indeed taken place [5]. The structural reconstruction property, called 'memory effect' forms the basis of regeneration for adsorbent LDH and the main mechanism of dye adsorption by CLDH though surface adsorption is presumed to have taken place as well [19]. This should be possible as surface area of calcined LDH has been reported to increase compared to its precursor LDH. On the basis of larger surface area of CLDH relative to $\mathrm{LDH}$, it is fair to assume that CLDH offers better adsorption efficiency than its precursor. 


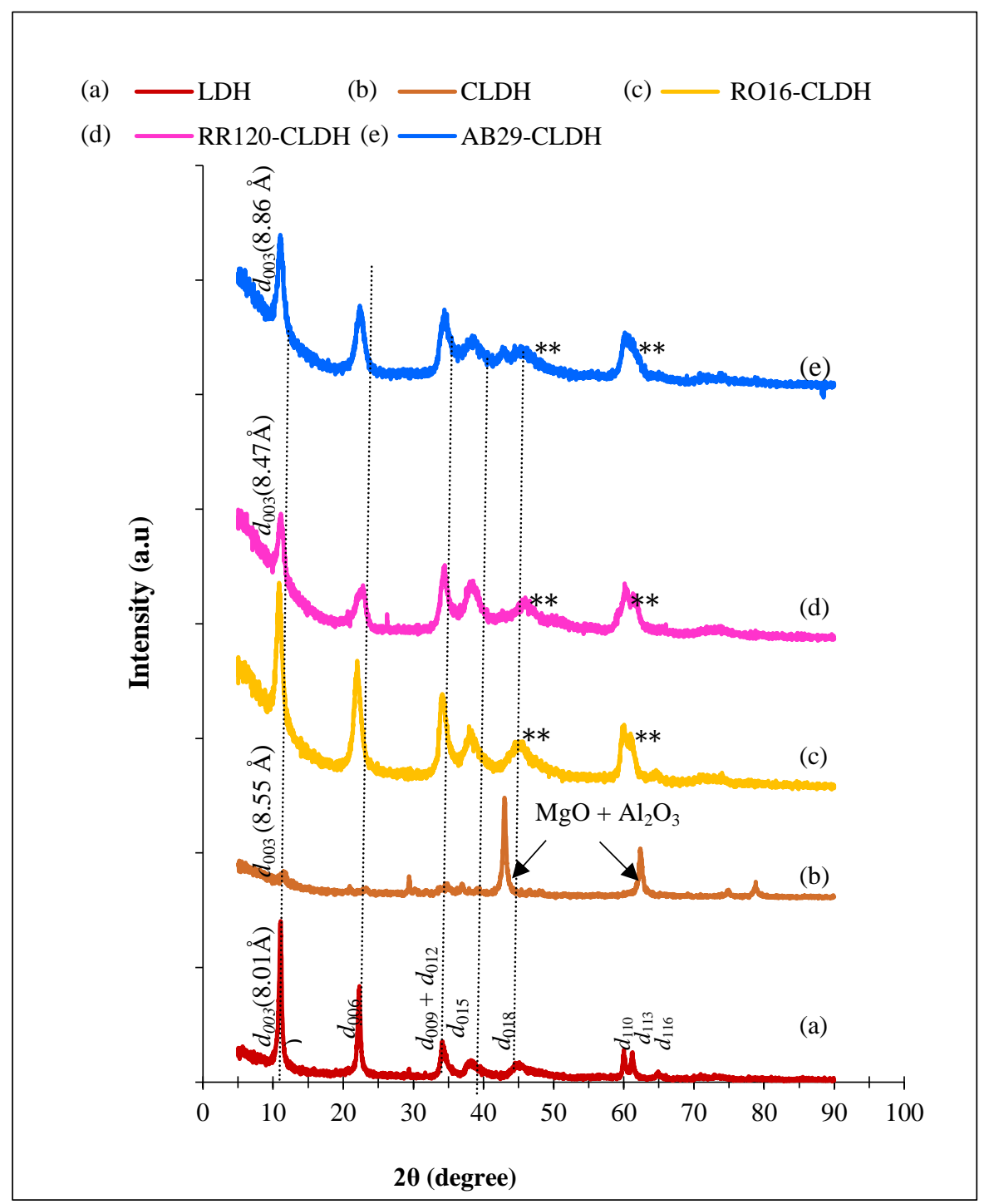

Figure 3. X-Ray Diffraction for LDH, CLDH and Dye loaded CLDH

\section{Scanning electron microscopy}

The textural properties of the LDH, CLDH and dye-loaded CLDHs have been investigated by scanning electron microscopy, as shown in Fig. $4(\mathrm{a}-\mathrm{e})$. It can be seen that the LDH image presents thin irregular aggregates of hexagonal platelets while CLDH resembles bigger platelets with rounded edges, with some still retaining the hexagonal-shaped of precursor LDH materials that were still retained in the CLDH product. This observation was understandable since both $\mathrm{LDH}$ and $\mathrm{CLDH}$ gave the same $\mathrm{N}_{2}$ adsorption-desorption analysis results [21]. It has been reported that during thermal decomposition of $\mathrm{LDH}$, the evolution of gas such as $\mathrm{CO}_{2}$ (from carbonate) or $\mathrm{NO} / \mathrm{NO}_{2}\left(\mathrm{NO}_{x}\right)$ from nitrate took place through fine pores at the brucite-like $\left(\mathrm{Mg}(\mathrm{OH})_{2}\right)$ layers, inducing the creation of channels and chimneys, which account for the increase surface area for calcined LDH. Since adsorption is a surface phenomenon, increase in surface area would enhance adsorption by CLDH. In the current study, the BET surface area for CLDH was found to be $121.58 \mathrm{~m}^{2} / \mathrm{g}$ compared to $82.74 \mathrm{~m}^{2} / \mathrm{g}$ for uncalcined LDH. Closer examination on SEM images in Fig.4 $(\mathrm{a}-\mathrm{e})$ reveals that dye materials have been incorporated onto the CLDH. 

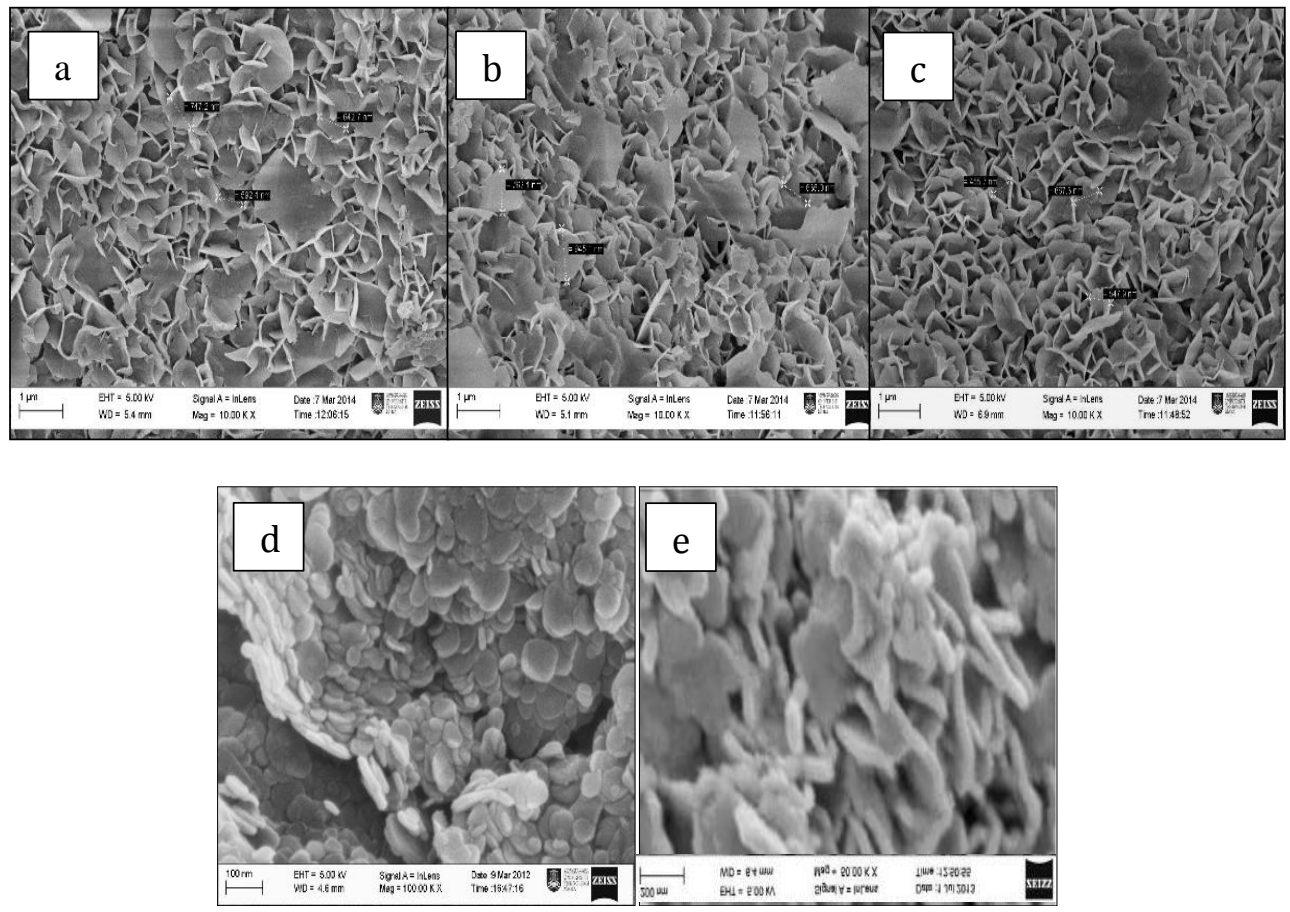

Figure 4. SEM images of (a) AB29-CLDH, Mag.:10K, (b) RO16-CLDH, Mag.:10 K, (c) RR120-CLDH, Mag.:10K, (d) LDH, Mag.: $100 \mathrm{~K}$ and (e) CLDH, Mag.: $50 \mathrm{~K}$

\section{Infrared spectra}

The FTIR spectra of LDH, CLDH and dye-loaded CLDHs are presented in Figure 5. The LDH spectrum resembles that of other hydrotalcite-like phases with $\mathrm{NO}_{3}^{-}$as the interlayer anions. The broad band at $3455-3500 \mathrm{~cm}^{-1}$, with a weak shoulder near $3100 \mathrm{~cm}^{-1}$ is due to the interlayer water molecules and the $\mathrm{H}$-bonded stretching vibration respectively [7, 22, 23]. The weak peak at $1637 \mathrm{~cm}^{-1}$ may be assigned to the $\mathrm{H}_{2} \mathrm{O}$ bending vibration of interlayer water, while the strong peak at $1384 \mathrm{~cm}^{-1}$ is attributed to the vibration of nitrate species. The bands in the range of $500-700 \mathrm{~cm}^{-1}$ are indicative of metal-oxygen-metal stretching [23].

Figure 5 shows the absorption bands of dye-loaded CLDH. It may be not plausible to exactly quantify the amount of $\mathrm{NO}_{3}^{-}$the LDH or CLDH by FT-IR spectroscopy, but the reduced intensity of the nitrate peaks with reference to the broad band at $3450 \mathrm{~cm}^{-1}$ and at $1637 \mathrm{~cm}^{-1}$ after dye uptake indicate that anion exchange between $\mathrm{NO}_{3}^{-}$ion and dye molecules did take place. The absorption band at around $1421 \mathrm{~cm}^{-1}$ in CLDH is indicative of the presence of $\mathrm{CO}_{3}^{2-}$ in the interlayer. The presence of $\mathrm{CO}_{3}^{2-}$ as an impurity may be difficult to avoid under the prevailing experimental conditions with the readiness of CLDH to take up moisture containing $\mathrm{CO}_{2}$. The expected intercalation of dye in the CLDH interlayer may also be discerned by the presence of absorption band in the region around 1200 $\mathrm{cm}^{-1}$ which can be attributed to $\mathrm{C}-\mathrm{H}$ bending vibration of aromatic dye molecules. The band occurring between $1450 \mathrm{~cm}^{-1}$ and $1380 \mathrm{~cm}^{-1}$ corresponds to the stretching mode of an azo-compound. The presence of sulfate $\mathrm{S}=\mathrm{O}$ stretching vibration bands at around $1000-1250 \mathrm{~cm}^{-1}$ and $1065 \mathrm{~cm}^{-1}$ due to sulfonic group in the dyes' structures were also observed. The result indicated that the dyes had existed on the surface of the CLDH after adsorption. 


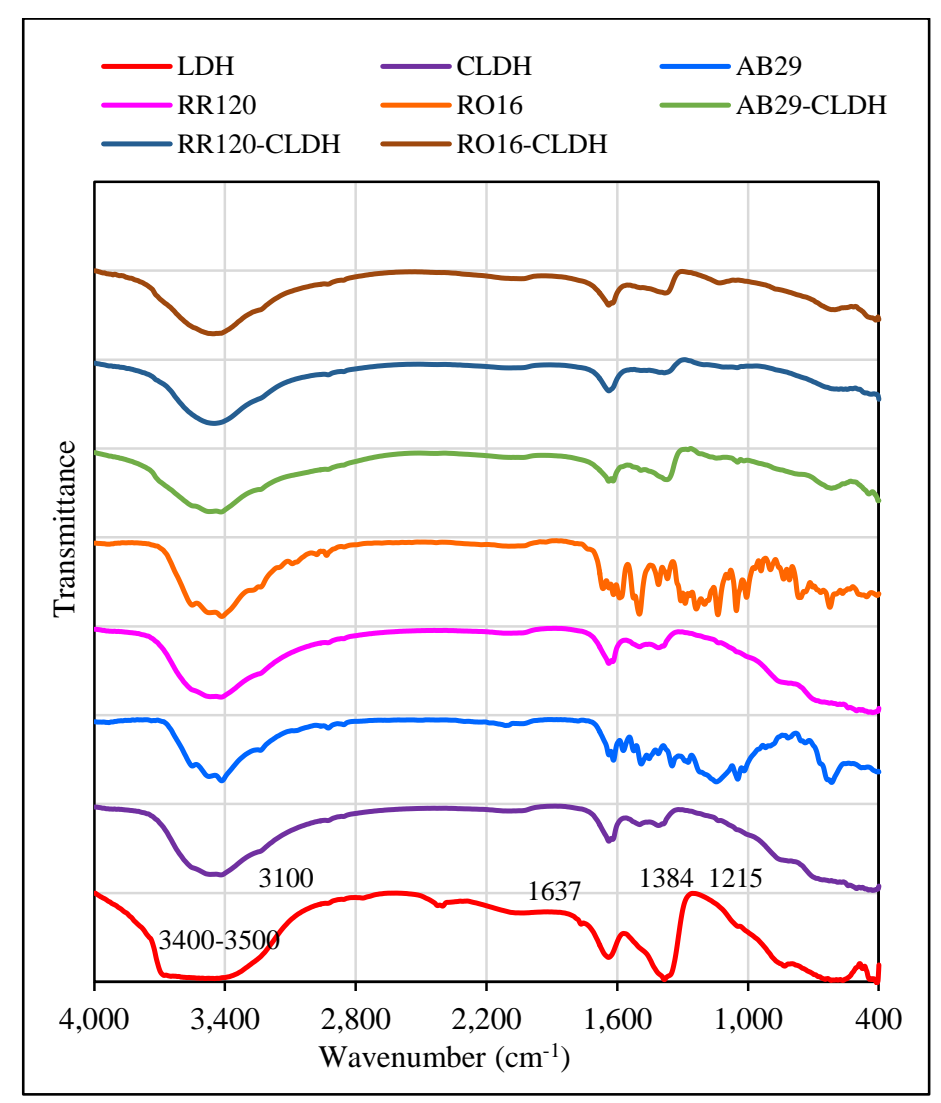

Figure 5. FTIR spectra of LDH, CLDH, dyes and dye-loaded CLDH, respectively

\section{Effect of contact time and initial dye concentrations}

The effect of contact time on and initial concentrations on dye removal by CLDH was compared with dye removal by LDH. The results for AB29, RO16 and RR120 are depicted in Figure $6(\mathrm{a}-\mathrm{c})$ for adsorption capacity, $q_{\mathrm{t}}, \mathrm{mg} / \mathrm{g}$. Figure 6 shows that adsorption capacity increased with increased contact time until equilibrium was attained and thereafter remained almost unchanged after contact time of approximately $150-180 \mathrm{~min}$. For both LDH and $\mathrm{CLDH}$, the adsorption capacity of dye increased rapidly within the first $10-20 \mathrm{~min}$, after which the rate of adsorption decreased with time until it gradually approached a plateau due to the continuous decrease in the concentration driving force.

The time curves of dye removal for concentrations $50-100 \mathrm{mg} / \mathrm{L}$ in Figure $6(\mathrm{a}-\mathrm{c})$ are smooth and continuous indicating the possibility of a monolayer formation on adsorbent surface [16][23]. As Figure $6(\mathrm{a}-\mathrm{c})$ depict, the maximum adsorption capacity by CLDH and LDH decreased with increasing initial dye concentration as the number of moles of dye competing for the available surface area of the adsorbent which was fixed for a constant adsorbent dose, increased [16]. The most significant observation in this experiment was the enhanced dye uptake, both in terms of percentage dye removal and adsorption capacity by CLDH over its precursor LDH for any given initial dye concentration. Examples of this elevated dye removal by CLDH over its precursor LDH are highlighted for 50 and $100 \mathrm{mg} / \mathrm{L}$ dye concentration for AB29, RO16 and RR120 in Table 1, which shows the values of $q_{\mathrm{t}}$ $(\mathrm{mg} / \mathrm{g})$. Calculation for (dye uptake by CLDH/dye uptake by LDH) ratio reveals that the increase was between 150 - $200 \%$. The increase uptake by CLDH was attributed largely to the 'memory effect' phenomenon which is synonym with structural reconstruction by calcined LDH to its original layered structure when exposed to aqueous solution containing ions such as simple inorganic ions (eg. $\mathrm{CO}_{3}^{2-}, \mathrm{SO}_{4}^{2-}, \mathrm{SeO}_{3}^{2-}, \mathrm{CO}_{3}^{2-}, \mathrm{NO}_{3}^{-}, \mathrm{Cl}^{-}$) or polar organic molecules [5]. Among the three dyes, AB29 exhibit the highest dye uptake followed by RO16 and RR120, the same 
trend as uptake by pristine LDH. This trend is reflective of binding capacity of these dyes towards the adsorbent $\mathrm{LDH}$ and $\mathrm{CLDH}$.

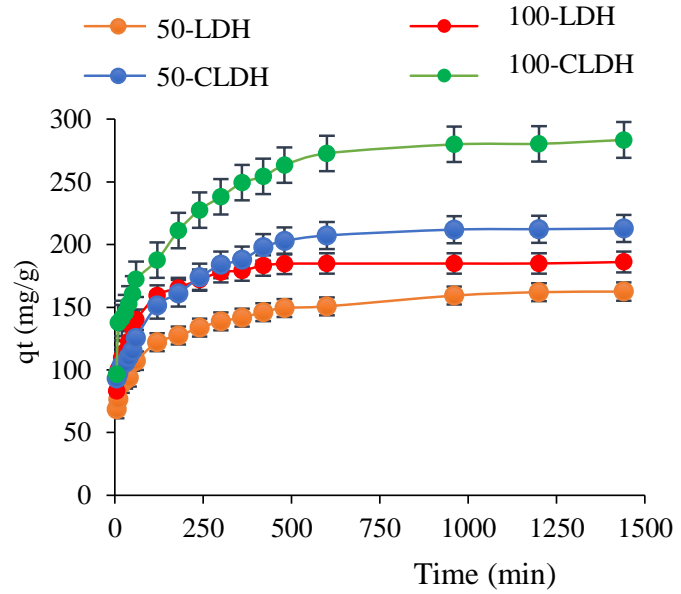

(a) AB29

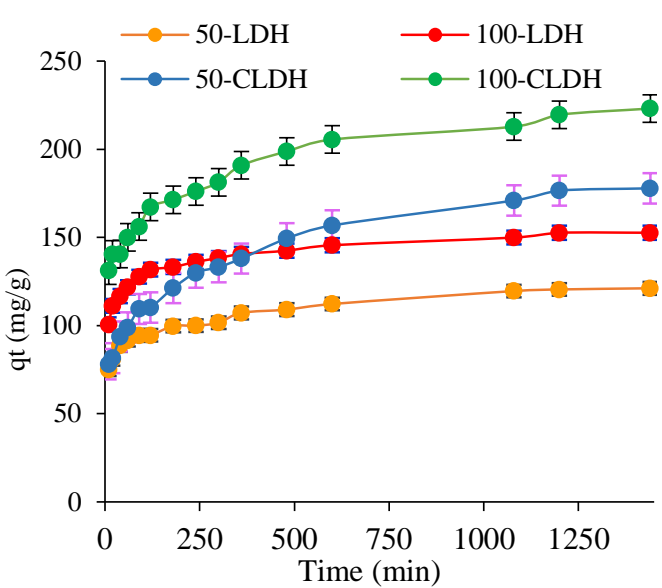

(b) $\mathrm{RO} 16$

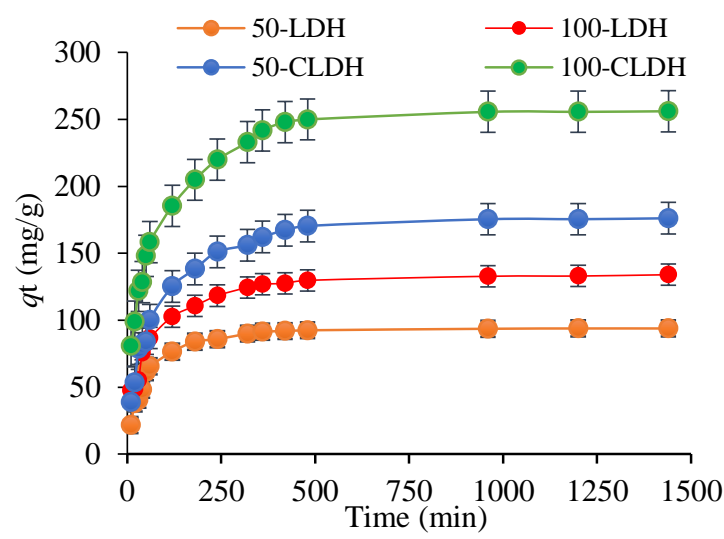

(c) RR120

Figure 6. Effect of contact time and initial dye concentrations on adsorption capacity in adsorption by LDH and CLDH on anionic dyes (a)AB29, (b) RO16 and (c) RR120

\section{Kinetic of adsorption}

The kinetic parameters for PFO, PSO and IPD kinetic models for dye-LDH and dye-CLDH obtained using experimental data for Figure 6 are summarised in Tables 2, 3 and 4, respectively. It is apparent that the values of correlation coefficient $\left(R^{2}\right)$ are mostly quite high (>0.9) for PFO, PSO and IPD models. Based on the correlation coefficient $\left(R^{2}\right)$, it can be seen that PSO have better fitting $\left(R^{2}=0.99-1.00\right)$ than PFO $\left(R^{2}=0.85-0.99\right)$. Furthermore the values of $q_{\mathrm{e}}$ calculated $\left(q_{\mathrm{e}}\right.$ alc $)$ from PSO model are more consistent with the experimental $q_{\mathrm{e}}$ $\left(q_{\text {e,expt }}\right)$, indicating that the experimental kinetic data for AB29, RO16 and RR120 adsorption by LDH and CLDH are suitable for this model. Similar finding was obtained by [17] on Reactive Orange 10 adsorption by CLDH. In addition, the values of $\left(q_{\mathrm{e}}\right.$, calc $)$ and $q_{\mathrm{e}}\left(q_{\mathrm{e} \text {,expt. }}\right)$ shows that maximum adsorption capacities are higher for CLDH than 
those by LDH. The results are consistent with CLDH being a more efficient adsorbent than LDH as dye scavenger from solution. The order of adsorption affinity for adsorbent is reflected from the values of the adsorption capacities. It can be seen that the order of affinity of adsorbent for dyes under study is AB29>RO16>RR120. This trend was obeyed by systems, dye-LDH and dye-CLDH.

Table 1. Comparison between dye uptake by LDH and CLDH in terms of adsorption capacity, $\left(q_{\mathrm{t} \text { expt }}\right)$ at $t=24 \mathrm{~h}, \mathrm{~T}=25^{\circ} \mathrm{C}, W / V=0.2 \mathrm{~g} / \mathrm{L}$ for $\mathrm{AB} 29, \mathrm{RO} 16$ and $\mathrm{RR} 120$, respectively

\begin{tabular}{|c|c|c|c|}
\hline \multirow{3}{*}{ Dye } & \multirow{3}{*}{ Adsorbent } & \multicolumn{2}{|c|}{ Concentration } \\
\hline & & $50 \mathrm{mg} / \mathrm{L}$ & $100 \mathrm{mg} / \mathrm{L}$ \\
\hline & & qt $(\mathrm{mg} / \mathrm{g})$ & qt $(\mathrm{mg} / \mathrm{g})$ \\
\hline \multirow[t]{2}{*}{ AB29 } & LDH & 162.501 & 186.100 \\
\hline & CLDH & 212.830 & 283.506 \\
\hline \multirow[t]{2}{*}{ RO16 } & LDH & 121.160 & 152.655 \\
\hline & CLDH & 177.858 & 268.140 \\
\hline \multirow[t]{2}{*}{ RR120 } & LDH & 96.338 & 133.979 \\
\hline & CLDH & 176.155 & 256.074 \\
\hline
\end{tabular}

To understand this trend, factors that influence dye binding capacity to adsorbent have to be considered. These factors include the characteristics and chemistry of the dye such as molecule structure, molecular weight, spatial and steric effect, all of which exert influence on the adsorption onto adsorbent either singly or in concert with other factors present in the aqueous environment. In this case AB9 and RO16, having smaller size than RR120 would be more unhindered during adsorption compared to the bulkier RR120 in terms of spatial and steric effect, even though RR120 has six sulfonic groups $\left(\mathrm{SO}_{3}^{-}\right)$compared to two in AB29 and RO16. As a result RR120 would have less mobility in attaching itself to adsorbent, even though the sulfonic groups render negative charge to the RR120, thus enhancing the dye ability to attach itself onto positively-charged adsorbent. In terms of negative charges, AB29 would be expected to have similar binding capacity. The fact that acid dye AB29 displayed better binding capacity than vinylsulphone reactive dye RO16 is probably due to a side reaction of RO16 in water. The vinylsulphone group $\left(-\mathrm{CH}_{2} \mathrm{CH}_{2} \mathrm{SO}_{2}-\right)$ in $\mathrm{RO} 16$ is electron attracting group which induces electron deficiency on the terminal carbon atom, initiating a nucleophilic (addition reaction) attack by electron rich hydroxyl ion, $\mathrm{OH}^{-}$from water. This hydrolysis can be represented by the reaction:

$$
\text { Dye- } \mathrm{SO}_{2} \mathrm{CH}=\mathrm{CH}_{2}+\mathrm{H}-\mathrm{OH} \longrightarrow \text { Dye- } \mathrm{SO}_{2}-\mathrm{CH}_{2}-\mathrm{CH} 2-\mathrm{OH}
$$

As a result of this hydrolysis, RO16 is less available for binding sites on LDH/CLDH with an overall reduction in binding capacity of RO16.

The resulting IPD linear plots of $q_{\mathrm{t}}$ versus $t^{0.5}$ (not shown) show the existence of two or three-staged linear curves, none of which pass through the origin. This is an indication that IPD was not the sole rate limiting step. Moreover, the existence a two or three-linear phases for each concentration implies that most likely the adsorption process involved more than one rate equation. 
Siti Mariam et al: ADSORPTION OF ANIONIC DYES FROM AQUEOUS SOLUTIONS BY CALCINED AND UNCALCINED Mg/Al LAYERED DOUBLE HYDROXIDE

Table 2. Pseudo-first order and pseudo-second-order kinetic parameters for dye-LDH system for AB29, RO16 and RR120, $W / V=0.2 \mathrm{~g} / \mathrm{L}, \mathrm{T}=25^{\circ} \mathrm{C}$

\begin{tabular}{|c|c|c|c|c|c|c|c|c|c|}
\hline \multicolumn{2}{|c|}{ AB29-LDH } & \multicolumn{4}{|c|}{ Pseudo first-order } & \multicolumn{4}{|c|}{ Pseudo second-order } \\
\hline $\begin{array}{c}\mathrm{Co} \\
(\mathrm{mg} / \mathrm{L})\end{array}$ & $\begin{array}{c}q_{\mathrm{e}, \mathrm{expt} \cdot} \\
(\mathbf{m g} / \mathbf{g})\end{array}$ & $\begin{array}{l}q_{\mathrm{e}}, \text { calce } \\
(\mathrm{mg} / \mathrm{g})\end{array}$ & $\begin{array}{l}k_{1 \times} 10^{-3} \\
(1 / \mathrm{min})\end{array}$ & $\begin{array}{c}h_{1} \times 10^{-1} \\
(\mathrm{mg} / \mathrm{g} \cdot \mathrm{min})\end{array}$ & $R^{2}$ & $\begin{array}{l}q_{\mathrm{e}} \text {, calce } \\
(\mathrm{mg} / \mathrm{g})\end{array}$ & $\begin{array}{c}k_{2} \times 10^{-4} \\
(\mathrm{mg} / \mathrm{g} \min )\end{array}$ & $\begin{array}{c}\boldsymbol{h}_{2} \\
\text { (mg/g.min) }\end{array}$ & $\boldsymbol{R}^{2}$ \\
\hline 50 & 162.500 & 122.462 & 4.836 & 5.923 & 0.988 & 156.250 & 1.74 & 5.970 & 0.998 \\
\hline 100 & 186.100 & & 4.145 & & & & & & 0.994 \\
\hline \multicolumn{2}{|c|}{ RO16-LDH } & \multicolumn{4}{|c|}{ First-order kinetic } & \multicolumn{4}{|c|}{ Second-order kinetic } \\
\hline $\begin{array}{c}\mathrm{Co} \\
(\mathrm{mg} / \mathrm{L})\end{array}$ & $\begin{array}{c}q_{\mathrm{e}, \mathrm{expt} \cdot} \\
(\mathrm{mg} / \mathrm{g})\end{array}$ & $\begin{array}{l}q_{\mathrm{e}}, \mathrm{calc} \cdot \\
(\mathrm{mg} / \mathrm{g})\end{array}$ & $\begin{array}{l}k_{1 \times} 10^{-3} \\
(1 / \mathrm{min})\end{array}$ & $\begin{array}{c}h_{1} \times 10^{-3} \\
(\mathrm{mg} / \mathrm{g} \cdot \mathrm{min})\end{array}$ & $R^{2}$ & $\begin{array}{l}q_{\mathrm{e}} \text {, calc• } \\
(\mathrm{mg} / \mathrm{g})\end{array}$ & $\begin{array}{c}k_{2} \times 10^{-4} \\
(\mathrm{mg} / \mathrm{g} \min )\end{array}$ & $\begin{array}{c}h_{2} \\
\mathrm{mg} / \mathrm{g} . \mathrm{min}\end{array}$ & $R^{2}$ \\
\hline 50 & 121.160 & & 2.764 & 2.533 & 0.944 & & 6.38 & 7.225 & 0.992 \\
\hline 100 & 152.655 & & 2.533 & 2.764 & 0.946 & 185 & 3.36 & 11.534 & 0.999 \\
\hline \multicolumn{2}{|c|}{ RR120-LDH } & \multicolumn{4}{|c|}{ First-order kinetic } & \multicolumn{4}{|c|}{ Second-order kinetic } \\
\hline $\begin{array}{c}\mathrm{C}_{0} \\
(\mathrm{mg} / \mathrm{L})\end{array}$ & $\begin{array}{r}q_{\text {e,expt} \cdot} \\
(\mathrm{mg} / \mathrm{g})\end{array}$ & $\begin{array}{l}q_{\mathrm{e}} \text {, calce } \\
(\mathrm{mg} / \mathrm{g})\end{array}$ & $\begin{array}{l}k_{1 \times} 10^{-3} \\
(1 / \mathrm{min})\end{array}$ & $\begin{array}{c}h_{1} \times 10^{-1} \\
(\mathrm{mg} / \mathrm{g} \cdot \mathrm{min})\end{array}$ & $R^{2}$ & $\begin{array}{l}q_{\mathrm{e}} \text {, calce } \\
(\mathrm{mg} / \mathrm{g})\end{array}$ & $\begin{array}{c}k_{2} \times 10^{-4} \\
(\mathrm{~g} / \mathrm{mg} \min )\end{array}$ & $\begin{array}{c}h_{2} \times 10^{-3} \\
(\mathrm{mg} / \mathrm{g} \text { min }\end{array}$ & $R^{2}$ \\
\hline 50 & 96.338 & 57.610 & 8.291 & 4.78 & 0.982 & 96.154 & 3.553 & 3.286 & 1.000 \\
\hline 100 & 133.979 & 79.177 & 6.448 & 5.11 & 0.983 & 136.986 & 2.132 & 4.002 & 1.000 \\
\hline
\end{tabular}

Table 3. Pseudo-first order and pseudo-second-order kinetic parameters for dye-CLDH system for AB29, RO16 and RR120, $W / V=0.2 \mathrm{~g} / \mathrm{L}, \mathrm{T}=25^{\circ} \mathrm{C}$

\begin{tabular}{|c|c|c|c|c|c|c|c|c|c|}
\hline \multicolumn{2}{|c|}{ AB29-CLDH } & \multicolumn{4}{|c|}{ Pseudo first-order } & \multicolumn{4}{|c|}{ Pseudo second-order } \\
\hline $\begin{array}{c}\mathrm{Co} \\
(\mathrm{mg} / \mathrm{L})\end{array}$ & $\begin{array}{c}q_{\mathrm{e}, \mathrm{expt} \cdot} \\
(\mathrm{mg} / \mathrm{g})\end{array}$ & $\begin{array}{l}q_{\mathrm{e}} \text {, calc. } \\
(\mathrm{mg} / \mathrm{g})\end{array}$ & $\begin{array}{l}k_{1 \times} 10^{-3} \\
(1 / \mathrm{min})\end{array}$ & $\begin{array}{c}h_{1} \times 10^{-1} \\
(\mathrm{mg} / \mathrm{g} \cdot \mathrm{min})\end{array}$ & $R^{2}$ & $\begin{array}{c}q_{\mathrm{e}}, \text { calc } \\
(\mathbf{m g} / \mathbf{g})\end{array}$ & $\begin{array}{c}k_{2} \times 10^{-5} \\
(\mathrm{~g} / \mathrm{mg} \mathrm{min}) \\
\end{array}$ & $\begin{array}{c}h_{2} \\
(\mathrm{mg} / \mathrm{g} \text { min) } \\
\end{array}$ & $R^{2}$ \\
\hline 50 & 212.83 & 103.514 & 4.606 & 5.719 & 0.946 & 250.000 & 8.84 & 5.525 & 0.998 \\
\hline 100 & 283.506 & 141.254 & 2.303 & 3.253 & 0.991 & 333.333 & 6.34 & 7.042 & 0.998 \\
\hline \multicolumn{2}{|c|}{ RO16-CLDH } & \multicolumn{4}{|c|}{ Pseudo first- order } & \multicolumn{4}{|c|}{ Pseudo second-order } \\
\hline $\begin{array}{c}\mathrm{Co} \\
(\mathrm{mg} / \mathrm{L})\end{array}$ & $\begin{array}{c}q_{\mathrm{e}, \mathrm{expp}} \cdot \\
(\mathrm{mg} / \mathrm{g})\end{array}$ & $\begin{array}{l}q_{\mathrm{e}}, \text { calce } \\
(\mathrm{mg} / \mathrm{g})\end{array}$ & $\begin{array}{l}k_{1 \times} 10^{-3} \\
(1 / \mathrm{min})\end{array}$ & $\begin{array}{c}h_{1} \times 10^{-1} \\
(\mathrm{mg} / \mathrm{g} \cdot \mathrm{min})\end{array}$ & $R^{2}$ & $\begin{array}{c}q_{\mathrm{e}}, \text { calc• } \\
(\mathrm{mg} / \mathrm{g})\end{array}$ & $\begin{array}{c}k_{2} \times 10^{-5} \\
(\mathrm{~g} / \mathrm{mg} \min )\end{array}$ & $\begin{array}{c}h_{2} \times 10^{-3} \\
(\mathrm{mg} / \mathrm{g} \min )\end{array}$ & $R^{2}$ \\
\hline 50 & 177.858 & 105.196 & 3.224 & 2.423 & 0.965 & 181.818 & 7.944 & 2.631 & 0.994 \\
\hline 100 & 268.140 & 111.764 & 3.224 & 3.603 & 0.958 & 277.778 & 7.840 & 6.050 & 0.999 \\
\hline \multicolumn{2}{|c|}{ RR120-CLDH } & \multicolumn{4}{|c|}{ Pseudo first-order } & \multicolumn{4}{|c|}{ Pseudo second-order } \\
\hline $\begin{array}{c}\text { Co } \\
(\mathrm{mg} / \mathrm{L})\end{array}$ & $\begin{array}{c}q_{\mathrm{e}, \mathrm{expt} \cdot} \\
(\mathrm{mg} / \mathrm{g})\end{array}$ & $\begin{array}{l}q_{\mathrm{e}}, \text { calc. } \\
(\mathrm{mg} / \mathrm{g})\end{array}$ & $\begin{array}{l}k_{1 \times} 10^{-3} \\
(1 / \mathrm{min})\end{array}$ & $\begin{array}{c}h_{1} \\
\text { (mg/g.min) } \\
\end{array}$ & $R^{2}$ & $\begin{array}{c}q_{\mathrm{e}}, \text { calc. } \\
(\mathrm{mg} / \mathrm{g})\end{array}$ & $\begin{array}{l}k_{2} \times 10-10^{-4} \\
(\mathrm{~g} / \mathrm{mg} \mathrm{min})\end{array}$ & $\begin{array}{c}h_{2} \mathrm{x} \\
(\mathrm{mg} / \mathrm{g} \min ) \\
\end{array}$ & $R^{2}$ \\
\hline 50 & 176.155 & 97.275 & 4.376 & 0.4256 & 0.938 & 181.818 & 3.6 & 3.824 & 1.000 \\
\hline 100 & 256.074 & 168.578 & 6.909 & 1.1647 & 0.992 & 344.828 & 0.58 & 11.136 & 1.000 \\
\hline
\end{tabular}

The calculated values of IPD rate constant, $k_{\mathrm{p}}, \mathrm{C}$ and the $R^{2}$ values summarized in Table 4 were obtained through fitting the experimenal data at second linear portion of Equation (3)[24]. The correlation coefficients for IPD diffusion model obtained are between 0.746 and 0.979 . The $R^{2}$-values are quite high and some are close to unity 
indicating the validity of application of this model. The values of IPD rate constant, $k_{p}$ decreased with decreasing initial dye concentration which provided the driving force in overcoming the resistance due to mass transfer [24] and was found to be correlated with the initial dye concentration. The values of $C$ give an idea about the thickness of the boundary layer, i.e. the larger the intercept the greater is the boundary layer effect (mass resistance), and the greater is the contribution of the surface adsorption in the rate limiting step[25]. In conclusion the adsorption mechanism of dye uptake by LDH is quite a complex process and cannot be explained by a single kinetic model alone, but could have involved more than single type of kinetic mechanism, all of which may be operating simultaneously [26][27].

Table 4. Intraparticle diffusion constants at different initial dye concentrations at $25^{\circ} \mathrm{C}$ for dye-LDH and dye-CLDH system for AB29, RO16 and RR120; W/V $=0.2 \mathrm{~g} / \mathrm{L}, \mathrm{T}=25^{\circ} \mathrm{C}$

\begin{tabular}{|c|c|c|c|c|c|c|c|c|c|}
\hline \multirow{2}{*}{$\begin{array}{l}\text { Dye } \\
\text { LDH }\end{array}$} & \multirow[b]{2}{*}{$\begin{array}{c}\mathrm{C}_{\mathbf{0}} \\
\mathrm{mg} / \mathrm{L}\end{array}$} & \multicolumn{3}{|c|}{ Intraparticle diffusion model } & \multirow{2}{*}{$\begin{array}{l}\text { Dye } \\
\text { CLDH }\end{array}$} & \multirow[b]{2}{*}{$\begin{array}{l}\mathrm{C}_{\mathrm{o}} \\
\mathrm{mg} / \mathrm{L}\end{array}$} & \multicolumn{3}{|c|}{ Intraparticle diffusion model } \\
\hline & & $\underset{\left(\mathrm{mg} / \mathrm{g} \cdot \min ^{0.5}\right)}{k_{\mathrm{p}}}$ & $\mathbf{C}$ & $R^{2}$ & & & $\underset{\left(\mathrm{mg} / \mathrm{g} \cdot \mathrm{min}^{0.5}\right)}{k_{\mathbf{p}}}$ & $\mathbf{C}$ & $\boldsymbol{R}^{2}$ \\
\hline AB29 & $\begin{array}{c}50 \\
100\end{array}$ & $\begin{array}{l}1.710 \\
1.333\end{array}$ & $\begin{array}{l}107.401 \\
151.071\end{array}$ & $\begin{array}{l}0.892 \\
0.746\end{array}$ & AB29 & $\begin{array}{c}50 \\
100\end{array}$ & $\begin{array}{l}4.396 \\
6.209\end{array}$ & $\begin{array}{l}104.172 \\
127.031\end{array}$ & $\begin{array}{l}0.983 \\
0.974\end{array}$ \\
\hline RO16 & $\begin{array}{c}50 \\
100\end{array}$ & $\begin{array}{l}0.4251 \\
0.8052\end{array}$ & $\begin{array}{l}91.001 \\
123.98\end{array}$ & $\begin{array}{l}0.955 \\
0.973\end{array}$ & RO16 & $\begin{array}{c}50 \\
100\end{array}$ & $\begin{array}{l}2.929 \\
2.643\end{array}$ & $\begin{array}{l}77.801 \\
132.03\end{array}$ & $\begin{array}{l}0.965 \\
0.952\end{array}$ \\
\hline RR120 & $\begin{array}{c}50 \\
100\end{array}$ & $\begin{array}{l}2.608 \\
2.302\end{array}$ & $\begin{array}{l}83.250 \\
77.438\end{array}$ & $\begin{array}{l}0.985 \\
0.957\end{array}$ & RR120 & $\begin{array}{c}50 \\
100\end{array}$ & $\begin{array}{l}4.095 \\
6.073\end{array}$ & $\begin{array}{l}83.252 \\
122.76\end{array}$ & $\begin{array}{l}0.979 \\
0.978\end{array}$ \\
\hline
\end{tabular}

\section{Mechanisms of adsorption by CLDH}

Results on dye removal had shown that CLDH exhibited better efficiency than its precursor LDH in removing anionic dyes from solution. The resulting calcined LDH (CLDH) has higher specific surface areas compared to its precursor LDH. Since adsorption is a surface phenomenon, this could be a major factor accounting for the significant increase in the anionic dye affinity for CLDH. During calcination process, fine pores and channels were generated as $\mathrm{H}_{2} \mathrm{O}$ vapor and $\mathrm{NO}_{2} / \mathrm{NO}$ gas were evolved, resulting in the creation of chimneys and channels in the particles, which ultimately resulted in the increase in specific surface area and smaller pores in the mesoporous CLDH particles.

The diffactograms of calcined materials shown in Figure 3 show that the CLDH displayed its 'memory effect' by reconstructing to its former LDH structure as evident through the re-emergence of (003) and (006) reflections. This is further supported by the observed of somewhat broadened, less symmetrical peaks with reduced intensity in comparison to the original LDH, indicating less ordered platelet-like structure and crystallinity [5], typical of post adsorption products following rehydration and reconstruction. It has been postulated that intercalation via reconstruction had played a role in this process of adsorption by CLDH according to Eq. (8), given the relatively slow increase in dye adsorption as dye concentration was increased (Figure 6). This 'memory effect' may be construed as a reconstruction reaction expressed as expressed by the preceding Equation (8) [21].

It may be concluded that under prevailing conditions, external surface adsorption appeared to be the main mechanism in the adsorption. Furthermore, the peaks corresponding to MgO in CLDH still remained in all CLDH products, indicating that reconstruction was not complete.

\section{Regeneration and recyclability}

Regeneration of adsorbent for possible reuse gives an advantage commercially and economically to an adsorbent. The results from four cycles of regeneration were obtained from calcination-hydration process whereby the adsorbed dyes was combusted during calcination, followed by rehydration of the regenerated adsorbent LDH in the 
dye solution. As shown in Figure 7, the thermally treated LDHs, exhibited progressive loss in percentage dye removal after each cycle. This percentage loss varied for each dye. After four cycles the efficiency has been reduced to almost $10-25 \%$, and may be regarded as uneconomical for further regeneration. A possible reason for the reduced efficiency is the reduced crystallinity of adsorbent, after undergoing repeated calcination-hydration process [28].
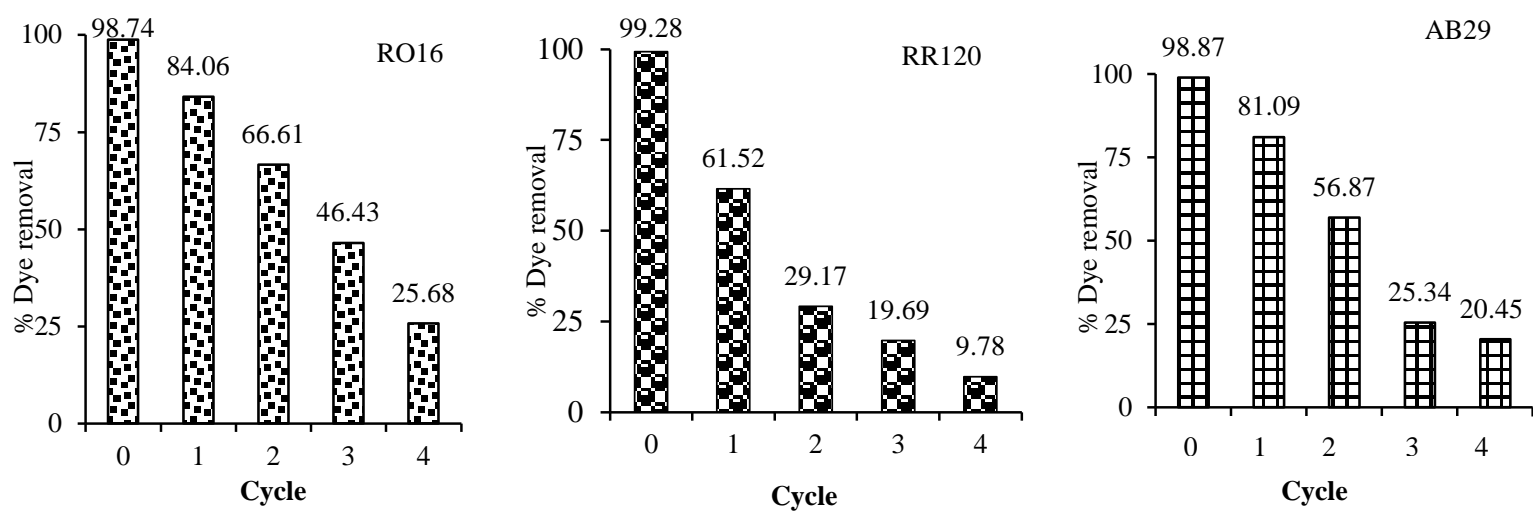

$C \mathrm{o}=50 \mathrm{mg} / \mathrm{L} ; W / V=0.1 \mathrm{~g} / 50 \mathrm{~mL}, 25^{\circ} \mathrm{C}$

Figure 7. Regeneration of CLDH after adsorption by RO16, RR120 and AB29

\section{Conclusion}

The adsorption of AB29, RO16 and RR120 was much more efficient by CLDHs than LDHs. Similarly, the adsorption capacities of CLDHs were much higher than that of its precursor LDHs. The affinity towards dye removal follows the order: AB29 > RO16 > RR120. Therefore CLDHs may be recommended for use in sequestering higher concentration of anionic dyes, while LDHs may be more appropriately used for low concentrations. The kinetics of adsorption of anionic dyes was well described by PSO reaction while PFO reaction and IPD kinetics may have contributed to the overall mechanism of dye uptake. Reconstruction of LDH via rehydration and intercalation was evident from X-ray diffraction and FTIR spectroscopy analysis. Recycling and reuse of LDH/CLDH was possible, until the fourth cycle when this is no longer economical. For better performance, only the second and third cycle may be considered when the percentage dye removal could still be maintained at 50 $-66 \%$ for these dyes.

\section{References}

1. El Gaini, L. Lakraimi, M., Sebbar, E., Meghea, A., and Bakasse, M. (2009). Removal of indigo carmine dye from water to $\mathrm{Mg}-\mathrm{Al}-\mathrm{CO} 3$-calcined layered double hydroxides. Journal of Hazardous Materials, 161: 627 632.

2. Lazaridis, N. K., Karapantsios, T. D. and Georgantas, D. (2003). Kinetic analysis for the removal of a reactive dye from aqueous solution onto hydrotalcite by adsorption. Water Research, 37: 3023 - 3033.

3. Abdelkader, N. B-H., Bentouami, A. Derriche, Z., Bettahara, N., de Menorval, L-C. Chemical. (2011). Synthesis and characterization of $\mathrm{Mg}-\mathrm{Fe}$ layer double hydroxides and its application on adsorption of Orange $\mathrm{G}$ from aqueous solution. Engineering Journal, 169: 231 - 238.

4. Das, J., Das, D. K. M. and Parida, K. M. (2006). Preparation and characterization of Mg-Al hydrotalcite-like compounds containing cerium, Journal of Colloid and Interface Science, 301: 569-574.

5. Auxilio, A. R., Andrews, P. C., Junk, P. C. and Spiccia, L. (2009). The adsorption behavior of C.I. Acid Blue 9 onto calcined $\mathrm{Mg}-\mathrm{Al}$ layered double hydroxides. Dyes and Pigments, 81: $103-112$. 
6. Das, J., Das, D. K. M. and Parida, K. M. (2006). Preparation and characterization of Mg-Al hydrotalcite-like compounds containing cerium, Journal of Colloid and Interface Science, 301: 569 -574.

7. Lagergren, S. (1898). About the theory of so called adsorption of soluble substances. K. Sven. Vetenskapsakad. Handl., Band 24, 1 - 39.

8. Ho, Y. S. (2006). Review of second-order models for adsorption systems. Journal of Hazardous Materials, 136: $681-689$.

9. Weber, W. J. and Morris, J. C. (1963). Kinetics of Adsorption on Carbon from Solution. Journal of the Sanitary Engineering Division, 89(2): 31 - 60.

10. Reichle, W. T. (1986). Synthesis of anionic clay minerals (mixed metal hydroxides, hydrotalcite). Solid State Ionics, 22: $135-141$.

11. Forano, C., Hibino, T., Lerouxa, F. C. and Taviot-Gue, H. (2006). Layered double hydroxides. Developments in Clay Science, 1: 1021 - 1095.

12. Kameda, T., Yamazaki, T. and Yoshioka, T. (2009). Preparation of MgAl layered double hydroxide intercalated with 2,7-Naphthalene Disulfonate and its selective uptake of aromatic compounds from aqueous solutions. Bulletin of the Chemical Society of Japan, 82: 1436 - 1440.

13. Mahmoodi, N. M., Hayati, B. and Arami, M. (2012). Kinetic, equilibrium and thermodynamic studies of ternary system dye removal using a biopolymer. Industrial Crops and Products, 35: 295 - 301.

14. Senthilkumaar, S., Kalaamani, P., Porkodi, K., Varadarajan, P. R. and Subburaam, C. V. (2006). Adsorption of dissolved reactive red dye from aqueous phase onto activated carbon prepared from agricultural waste. Bioresource Technology, 97: 1618 - 1625.

15. Yu, L. and Luo, Y. (2014). The adsorption mechanism of anionic and cationic dyes by Jerusalem artichoke stalk-based mesoporous activated carbon. Journal of Environmental Chemical Engineering, 2: 220 - 229.

16. Das, J., Das, D. K. M. and Parida, K. M. (2006). Preparation and characterization of Mg-Al hydrotalcite-like compounds containing cerium. Journal of Colloid and Interface Science, 301: 569 -574.

17. Bouhent, M. M., Derriche, Z., Denoyel, R., Prevot, V., and Forano, C. (2011). Thermodynamical and structural insights of orange II adsorption by MgRAlNO3 layered double hydroxides. Journal of Solid State Chemistry, 184: 1016 - 1024.

18. Bouraada, M., Belhalfaoui, F. and Ouali, M. S. (2009). Sorption study of an acid dye from an aqueous solution on modified Mg-Al layered double hydroxides. Journal of Hazardous Materials, 163: 463 - 467.

19. Extremera, R., Pavlovic, I., Pérez, M. R., and Barriga, C. (2012). Removal of acid orange 10 by calcined Mg/Al layered double hydroxides from water and recovery of the adsorbed dye. Chemical Engineering Journal, 213: $392-400$.

20. Zhu, M-X., Li, Y-P., Xie, M. and Xin, H-Z. (2005). Sorption of an anionic dye by uncalcined and calcined layered double hydroxides: A case study. Journal of Hazardous Materials, 120: 163 - 171.

21. Ni, Z. M., Xia, S. J., Wang, L. G., Xing, F. F. and Pan, G. X. (2007). Treatment of methyl orange by calcined layered double hydroxides in aqueous solution: Adsorption property and kinetic studies. Journal of Colloid and Interface Science, 316: 284 - 291.

22. Crepaldi, E. L., Tronto, J., Cardoso, L. P. and Valim, J. B. (2002). Sorption of terephthalate anions by calcined and uncalcined hydrotalcite-like compounds. Colloids and Surfaces A: Physicochemical and Engineering Aspects, 211: $103-114$.

23. Ferreira, O. P., Alves, O. L., Gouveia, D. X., Filho, A. G. S., de Paiva, J. A. C. and Filho, J. M. (2004). Thermal decomposition and structural reconstruction effect on $\mathrm{Mg}-\mathrm{Fe}-$ based hydrotalcite compounds. Journal of Solid State Chemistry, 177: 3058 - 3069.

24. Naveen, N., Saravanan, P., Baskar, G. and Sahadevan, R. (2011). Equilibrium and kinetic modeling on the removal of Reactive Red 120 using positively charged Hydrilla verticillata. Journal of the Taiwan Institute of Chemical Engineers, 42: 463 - 469.

25. Kobiraj, R., Gupta, N., Kushwaha, A. K. and Chattophadhyaya, M. C. (2012). Determination of equilibrium, kinetic and thermodynamic parameters for the adsorption of the brilliant green dye from aqueous solutions onto eggshell powder. Indian Journal of Chemical Technology, 20: 26 - 31.

26. Greluk, M. and Hubicki, Z. (2010).Kinetics, isotherm and thermodynamic studies of Reactive Black 5 removal by acid acrylic resins. Chemical Engineering Journal 162: 919 - 926. 
27. Baccar, R., Blánquez, P., Bouzid, J., Feki, M., Attiya, H. and Sarrà, M. (2013). Modelling of adsorption isotherms and kinetics of a tannery dye onto an carbon prepared from an agricultural by-product activated carbon prepared from an agricultural by-product. Fuel Processing Technology, 106: 408 - 415.

28. Ulibarri, M. A., Pavlovic, I.. Barriga, C. Hermos'in and Cornejo, M. C. (2001). Adsorption of anionic species on hydrotalcite-like compounds: effect of interlayer anion and crystallinity, Applied Clay Science, 18: 17 - 27. 